\title{
PROBLEM DISKRECIONOG OVLAŠTENJA
}

Da li je Ustavni sud Bosne i Hercegovine „politički sud“?

Ključne riječi

Diskreciono ovlaštenje, Ustavni sud BiH, politika, sudstvo, Bosna i Hercegovina

Autor

Dr Aleksandar Savanović je vanredni profesor Fakulteta političkih nauka Univerziteta $u$ Banjoj Luci.

Korespondencija

aleksandar.savanovic@fpn.unibl.org

Oblast

Politička teorija

\section{Sažetak}

U ovom tekstu analiziramo političku krizu koja je produkovana unutar bosanskohercegovačkog društva, odlukama Ustavnog suda Bosne i Hercegovine u slučajevima U-3/13, U-18/16 i U-22/16. Ovi slučajevi su važne studije slučaja za klasični problem političke filozofije i savremene jurisprudencije - naime: problem diskrecione moći najviših sudskih instanci (ustavnih i/ ili vrhovnih sudova). Da li najviša sudska institucija mora biti "politička" po definiciji? Ili "politički“ uticaj ustavnog/vrhovnog suda jeste rezultat njihove vlastite intencije za proširenjem vlastite moći $i$ uticaja? Uloga, praksa $i$ nasljeđe najviše sudske institucije u ekstremno podijeljenom društvu kakvo je u BiH, neka je vrsta eksperimenta u realnom vremenu za ovaj problem.

DOI

10.5937/politeia0-15661

UDK

341.218:323.17

Datum prijema članka

11.11.2017.

Datum konačnog prihvatanja članka za objavljivanje 
U savremenim demokratskim ustavnim političkim sistemima po logici stvari mora da postoji neka institucija koja ima ovlasti finalnog arbitra (Dworkin, 1978: 34; Rawls, 1993: 55-58; Hart, 1994: 126; Bellamy, 2007: 21), i to su po pravilu vrhovni i / ili ustavni sudovi. U slučaju Bosne i Hercegovine to je Ustavni sud, čija je deskripcija data u članu VI Ustava $\mathrm{BiH}$. U političkoj praksi $\mathrm{BiH}$ odluke Ustavnog suda često se susreću s izrazitim osporavanjima, kritikom javnosti i često se čak i ne sprovode u praksi. Razlog za to je u najvećem broju slučajeva tvrdnja koja dolazi od političkih predstavnika iz Republike Srpske da je to „bošnjački“ sud, tj. sud koji ima „dvostruke aršine“ i služi da sprovodi političku volju političkih predstavnika bošnjačkog naroda. U specifičnom kontekstu to se odnosi na tvrdnju da odluke Ustavnog suda reinterpretiraju istoriju $\mathrm{BiH}, \mathrm{i} /$ ili su represivno usmjerene protiv Srba i Republike Srpske (Savanović, 2016: 115-116). Tvrdnje o političkoj uzurpaciji Ustavnog suda u funkciji bošnjačkih politika ojačane su činjenicom da su odluke, naročito u osjetljivim apelacijama, u velikom broju slučajeva donosene preglasavanjem 3+2 naprema 2+2. ${ }^{1}$ Čitav niz odluka prošao je kroz tu vrstu interpretacije ili kvazinterpretacije. U ovom tekstu testira-

\footnotetext{
Ustav BiH čl.VI/1a određuje sastav Ustavnog suda po šemi: četri člana koja bira Predstavnički dom FBiH, dva člana bira NSRS, a tri člana bira predsjednik Evropskog suda za ljudska prava „nakon konsultacija s Predsjedništvom“. Kriterij je „entitetski“ a ne etnički jer Ustav ne propisuje proporcionalnu zastupljenost konstitutivnih naroda niti da sudije uopšte moraju da se izjašnjavaju o tom pitanju [Steiner, Ademović, 2010: 625]. Međutim, u praksi je ovo do sada značilo: Bošnjaci, Srbi i Hrvati daju po dva člana, a tri su strane sudije. To proizilazi iz činjenice da se sudije u entitetskim parlamentima biraju prostom većinom [Ustav RS, čl. 75; Ustav FBiH, čl. IV. A. 4. 19. Vidjeti: Steiner, Ademović, 2010: 626], pa je izvjesno da će izbor odražavati nacionalnu pripadnost. S obzirom na to da Sud donosi odluke prostom većinom, praksa je pokazala da je u nekoliko ,teških“ slučajeva osjetljivih po nacionalnom osnovu, došlo do preglasavanja tri strane sudije + dvojica sudija iz reda Bošnjaka.
}

ćemo te tvrdnje komparativnom analizom dva nedavna „slučaja“ vezana za praznike: odluke Ustavnog suda o 9.januaru kao Danu Republike Srpske, s jedne strane; i odlukama o 1.martu kao Danu nezavisnosti BiH, i 25. novembru kao Danu državnosti BiH.

Komparativna analiza ovih slučajeva je zapravo case study za jedno od dramatičnih pitanja savremene jurisprudencije kao i političke teorije: da li „jaki“ ustavni ili vrhovni sudovi po definiciji i nužnim načinom postaju jake političke institucije koje svojim djelovanjem modifikuju politički sistem date države (Hart, 1994: 97; Bellamy, 2007: 55,93). Na osnovu činjenice da nije moguć apsolutno čist pravni jezik te da nije moguća mehanička „algoritmska“ primjena fundamentalnih principa ustava kroz pravni sistem i legislativu države, potrebna je neka institucija koja će imati diskrecionu ovlast finalnog arbitratora. Uobičajeno rješenje je da to budu ustavni i/ili vrhovni sudovi i mnogi od prominentnih političkih i pravnih teoretičara zagovarali su ovaj model (Dworkin, 1978: 4,87,136 (ft1); Rawls, 1993: 231-240; Hart, 1994: 142,144,204) a on je i odomaćen u praksi. Međutim, u novijoj teoriji sve više je kritičara tog modela (Bellamy, 2007; Weale, 2013). U tradiciji podjele vlasti sudska vlast, a naročito najviše sudske instance, teže da budu u što većoj mjeri nezavisne od ostalih grana vlasti. U praksi to se obezbjeđuje različitim mehanizmima - od doživotnosti mandata do nedodirljivosti plata sudija i slično. Što su ti mehanizmi veći i širi sudovi su jači. Zagovornici jakih ustavnih sudova kao finalnih arbitratora insistiraju na sličnim mehanizmima. S druge strane, oni koji kritikuju takvu diskrecionu ovlast najviših sudskih instanci teže da ih što više ograniče djelovanjem predstavničkog tijela. Na primjer, time što će mandati biti ograničeni, kraći i/ ili opozivi od strane Parlamenta. 
Ustavni sud $\mathrm{BiH}$ jedan je od ekstremno jakih sudova tog tipa. Njegova snaga proizilazi ne samo iz standardnih mehanizama kao što su eksterna nedodirljivost mandata sudija (Ustav BiH, čl. VI/1c) i budžeta Suda (Steiner, Ademović, 2010: 629-630); već između ostalog i iz činjenice da sam propisuje svoj poslovnik o radu (Ustav BiH, čl.VI/2), tj. Pravila Ustavnoga suda Bosne i Hercegovine (Službeni glasnik $\mathrm{BiH}, 22 / 14$ ) te da ima ,široko postavljene,, (Steiner, Ademović, 2010: 623) nadležnosti koje prevazilaze uobičajne opsege jednog ustavnog suda: naime, pored zadatka da ocjenjuje ustavnosti zakona i kontrolu poštovanja osnovnih ljudskih prava iz Evropske konvencije, on se bavi i stvarima iz domena Vrhovnog suda. ${ }^{2}$ Zbog takve snage, Ustavni sud $\mathrm{BiH}$ izrazit je primjer problema koji se odnose na kontroverzu diskrecione ovlasti najviše sudske instance i analiza njegovog rada predstavlja važan praktični primjer za jedan težak teorijski problem, i svojevrstan eksperiment u realnom vremenu na tu temu.

\section{UVOD}

Po osnovu apelacije o ocjeni ustavnosti člana 3. b Zakona o praznicima Republike Srpske (Službeni glasnik Republike Srpske 43/07) koju je podnio Bakir Izetbegović, član Predsjedništva $\mathrm{BiH}$ iz reda bošnjačkog naroda, Ustavni sud $\mathrm{BiH}$ je 26. 11. 2015. u odluci U-3/13 odlučio da je taj član u suprotnosti sa članom I/2 Ustava $\mathrm{BiH}$, članom II/4. Ustava $\mathrm{BiH}$ (u vezi s članom 1.1 i članom 2 a i c Međunarodne konvencije i članom 1 Proto-

\footnotetext{
2 Prema članu VI/3(a) Ustava $\mathrm{BiH}$, data je nadležnost Ustavnom sudu da odlučuje da li je „bilo koja odredba ustava ili zakona jednog entiteta u skladu s Ustavom BiH“ (takođe: čl VI/3(c)) Član VI/3(b) daje „apelacionu nadležnost u pitanjima koja su sadržana u ovom ustavu kada ona postanu predmet spora zbog presude bilo kojeg suda u $\mathrm{BiH}^{\prime \prime}$.
}

kola broj 12 uz Evropsku konvenciju). Shodno tome naloženo je NSRS da usaglasi član 3b Zakona o praznicima s Ustavom $\mathrm{BiH}$.

Odlučujući u predmetu broj U-18/16, Ustavni sud Bosne i Hercegovine odbio je kao neutemeljen zahtjev 30 poslanika Narodne skupštine Republike Srpske za ocjenu ustavnosti Zakona o proglašenju 1. marta Danom nezavisnosti Republike Bosne i Hercegovine. Ustavni sud je utvrdio da je Zakon u skladu s dijelom preambule Ustava Bosne i Hercegovine koji glasi: „Bošnjaci, Hrvati i Srbi, kao konstitutivni narodi (u zajednici s ostalima), i građani Bosne i Hercegovine ovim utvrduju Ustav Bosne i Hercegovine“, članovima I/2 i II/4 Ustava Bosne i Hercegovine, članom 14 Evropske konvencije za zaštitu ljudskih prava i temeljnih sloboda, članom 1. Protokola broj 12 uz Evropsku konvenciju za zaštitu ljudskih prava i temeljnih sloboda, člankom 1.1 i članom 2 stavak (1) točke a), b), c), d) i e) Medunarodne konvencije o ukidanju svih oblika rasne diskriminacije. Isto tako, odlučujući u predmetu broj U-22/16, Ustavni sud Bosne i Hercegovine odbio je kao neutemeljen zahtjev 30 poslanika Narodne skupštine Republike Srpske za ocjenu ustavnosti članaka 1, 2 i 3 Zakona o proglašenju 25. novembra Danom državnosti Republike Bosne i Hercegovine.

\section{REAKCIJE}

S obzirom na to da ova dva slučaja tretiraju gotovo identičnu materiju po suštini (naime, pravo da se obilježava praznik bez diskriminacije drugih, a da su odluke suda u ova dva slučaja dijametralno suprotne), ovo djeluje kao prima facie dokaz o politički motivisanom djelovanju Ustavnog suda. Reakcije političkih predstavnika oba naroda samo produbljuju tu sumnju. Tako je Milorad Dodik, predsjednik Republike Srpske 
neposredno nakon odluke Ustavnog suda poručio sljedeće: „To nikada neće biti naši praznici. Ni minimalno povjerenje u Ustavni sud $\mathrm{BiH}$ više ne postoji. To je politička odluka motivisana isključivo donošenjem loših odluka za srpski narod. Argumentacija koju su upotrijebili u vezi sa našim praznikom (9. januar) sada ne važi u gotovo identičnoj situaciji kada oni imaju 1. mart, koji vrijeđa Srbec (Dodik, 2017). Kao moguću reakciju on je najavio: „Treba prestati bilo šta očekivati od tog suda, treba povući dvojicu srpskih sudija i učiniti to mjesto nelegitimnim" (Dodik, 2017). S druge strane, Bakir Izetbegović član Predsjedništva $\mathrm{BiH}$, iz reda bošnjačkog naroda, dao je sljedeći komentar: „Živimo svi u nezavisnoj $\mathrm{BiH}$, rođeni smo ovdje i trebamo voljeti ovu zemlju. Odluka Ustavnog suda je očekivana i pozdravljam je“ (Izetbegović, 2017). Na taj način nastavljena je standardna retorika koja uobičajeno prati odluke Ustavnog suda u mnogim „teškim“ i „kontroverznim“ slučajevima (Savanović, 2016).

\section{MERITUM}

Da bi se ove tvrdnje ispitale, potrebno je izložiti suštinske momente iz problematizovanih apelacija, tj. mi moramo u kratkim crtama proći kroz meritume spornih odluka.

\subsection{U-3/13}

U predmetu U-3/13 apelant je iznio više argumenata u prilog tvrdnji da je obilježavanje 9. januara kao Dana Republike - diskriminatorno. ${ }^{3}$ Ovi argumenti različiti su po

\footnotetext{
3 Prvobitno je apelacija osporavala i član 2.b Zakona o praznicima, ali je podnosilac povukao tu tvrdnju tokom javne rasprave (U-3/13: 42). To je sasvim logič no jer dotični član 2.b glasi: „Praznici u Republici su .. b) Dan Republike“, i očito je besmisleno tvrditi diskriminatornost ove apstraktne i uobičajene norme. Član 3.b definiše 9. januar kao datum obilježavanja Dana Republike.
}

suštini i značaju, a moguće ih je grupisati na više načina. ${ }^{4} \mathrm{Mi}$ ćemo se fokusirati na sljedeće argumentativne strategije:

I Tvrdnja da je 9. januar kao praznik „uspostavila 'Skupština srpskog naroda BiH’ još 1992. god.“ (U-3/13: 12;44). Argument tvrdi diskriminaciju na osnovu toga što u tadašnjem sazivu Skupštine nije bilo političkih predstavnika Bošnjaka i Hrvata. Neučešće Bošnjaka i Hrvata je, prema tvrdnji podnosioca, protivno ne samo Ustavu $\mathrm{BiH}$, već i samom Ustavu RS [čl. 1], koji definiše RS kao političku zajednicu ravnopravnih konstituivnih naroda (U-3/13: 18; 44).

II Dan 9. januar očito referiše na 9. januar 1992. kada je „Skupština srpskog naroda u BiH usvojila Deklaraciju o proglašenju Republike Srpskog Naroda BiH“ (U-3/13: 13. Tvrdi se da je Deklaracija sa Skupštine od 9. januara bila etnodiskriminatorna jer je kao jedan od ciljeva proklamovala „teritorijalno razgraničenje“ s druga dva naroda i formiranje ekskluzivno srpske države (U-3/13: 39). „Što će se kasnije pokazati ... tokom agresije na BiH kada je na tom teritoriju izvršeno sistematsko i plansko etničko čišćenje svih koji nisu Srbi“ (U-3/13:13;39). Podnosilac na ovaj način nepotrebno kontaminira apelaciju uvođenjem striktno političke ocjene, a stvar još dalje pogoršava tvrdnjom da taj datum „nije i nikada neće biti, datum koji će prihvatiti svi građani RS“(U-3/13: 15), jer je nemoguće

\footnotetext{
4 Npr. sudija Ustavnog suda $\mathrm{BiH}$ Zlatko $\mathrm{M}$ Knežević je to u svom izdvojenom mišljenju učinio na način: „Zahtjev za ocjenu ustavnosti ... svodi se na tvrdnju da Dan Republike ... predstavlja kršenje normi ustavnog karaktera ... simbolizira samo jedan narod ... donesen je volje druga dva naroda ... te da norme imperativnog karaktera u zakonu ukazuju na 'prinudnost' obilježavanja (U-3/13: 105). Sam Ustavni sud $\mathrm{BiH}$ definisao je svoj zadatak u ovom slučaju na sljedeći način: „ocijeniti a) da li 9 . januar predstavlja istorijsko nasljeđe samo jednog naroda u RS; b) da li praksa obilježavanja ... favorizira samo jedan narod“ (U-3/13: 74).
} 
za „nesrbe“ da se identifikuju sa simbolikom ovog datuma. ${ }^{5}$

III S obzirom na to da se Dan Republike „odnosi na sve građane“, iz prethodnog slijedi da 9. januar ne može biti datum koji će udovoljiti kriterijumima (U-3/13: 19). Razlog je: 9. januar označava „istorijski momenat samo jednog, srpskog naroda u RS“ (U-3/13: 44;70). To je stanovište koje je zauzela i Venecijanska komisija (U-3/13: 77).

IV Posebna klasa argumenata odnosi se na religijsku konotaciju 9. januara: koja proizilazi iz koincidencije da je 9. januar istovremeno i Sveti arhiđakon Stefan, krsna slava RS. S obzirom na to da je to vjersko obilježje samo pravoslavaca -Srba, to je po mišljenju podnosioca, očita diskriminacija (U-3/13: 20; 71), jer se „slavljenjem svjetovnog praznika na religijski način Srbi pravoslavci dovode u privilegovan položaj“ (U-3/13: 45; 88). Osim toga, time se krši načelo sekularne države i Zakon o slobodi vjere i pravnom položaju crkava i vjerskih zajednica u BiH (čl. 14. 1), koji zabranjuje promovisanje ili favorizovanje neke religije kao državne religije (U-3/13: 45; 53; 71).

V Naročito ako se ima u vidu „praksa“ obilježavanja Dana Republike: u obilježavanju Dana Republike masovno učestvuju sveštenici Srpske pravoslavne crkve, manifestacije uključuju mnogobrojnu pravoslavno-religijsku praksu - poput liturgije, „lomljenja slavskog kolača", pa sve do programa koji emituje Javni servis RTRS (U-3/13: 45). Zvanična

\footnotetext{
5 Posebno nesretan aspekt cijelog slučaja je pokušaj (re)interpretacije političke istorije $\mathrm{BiH}$. Apelant, sasvim neptrebno za osnvonu temu apelacije, tvrdi da je RS nastala 1995.godine u Dejtonu, dok se u RS 9.jan 1992. vidi kao moment istorijskog nastanka RS. Ulazeći u slučaj Ustavni sud je doveo sebe u apsurdnu situaciju da raspravlja o percepciji koja postoji o jednoj istorijskoj činjenici, koja je kao takva nepodložna ustavnosudskoj interpretaciji. Time je dao snažan argument onima koji tvrde da je funkcija Ustavnog suda $\mathrm{BiH}$ da reinterpretira istoriju $\mathrm{BiH}$ u antisrpskom maniru.
}

pozivnica koju upućuju institucije RS ima očit pravoslavno-religijski sadržaj.

VI Argument vezan za "praksu“ obilježavanja praznika ima i drugačiju, još važniju formu. Naime, postavlja se pitanje da li proslava bilo kog praznika može biti diskriminatorna prema nekom ukoliko način proslave ne uključuje neku vrstu prinude ili forsiranja neželjenih aktivnosti. Zakon o praznicima je problematičan u ovom smislu jer podrazumijeva obavezan neradni dan, i za one koji proslavljaju ali i za one koji to ne žele. ${ }^{6} \mathrm{Tj}$., zakon propisuje novčanu kaznu za one koji bi taj dan radili. Ovo je krucijalno važna primjedba, koju je u svom mišljenju istakla Venecijanska komisija (U-3/13: 33), jer omogućava da se prevlada jedna od suštinskih manjkavosti apelacije: naime, pozivanje na tvrdnju da ovaj datum „vrijeđa osjećanja“ Bošnjaka (U-3/13:70).7 To je, naravno, „veoma subjektivna percepcija podnosioca zahjteva" (U-3/13: 28), kako je to istaknuto u odgovoru NSRS. Osim toga, ona tretira kao stvar prava nešto što nije pravna materija "osjećaje“ ljudi. Nije zadatak Ustava da štiti bilo čija osjećanja i Ustavni sud ne bi smio da se bavi ovom tematikom (U-3/13:35). Ciljajući na tu poentu NSRS je ukazala da „nije moguće zaključiti na koja prava i slobode se odnosi eventualna diskriminacija“ (U-3/13: 36). Naprosto, ako neko želi da slavi i obilježava taj dan, on to može, a onaj ko ne želi - i ne mora. Tvrditi da je to što neko proslavlja nešto uvredljivo za nečija „osjećanja“ apsurdno je i pravno besmisleno - svaka proslava može da se tretira na taj način. ${ }^{8}$ Prihvatiti tako nešto vodilo bi do apsurdnih zaključa-

\footnotetext{
6 Zakon o praznicima Republike Srpske, čl. 5(1); čl.10; čl.11.

„Na kraju sve se svodi na tvrdnju da Bošnjaci u RS ... osjećaju diskriminaciju“ (U-3/13: 106).

8 Sličan argument iznio je u svom izdvojenom mišljenju sudija Ustavnog suda $\mathrm{BiH}$ Zlatko $\mathrm{M}$. Knežević.
} 
ka da proslava gola na fudbalskoj utakmici vrijeđa „osjećanja“ navijača protivničke ekipe pa je stoga diskriminatorna i sl. Ipak, ovaj argument podnosioca nije tako „subjektivna“ primjedba ako se ima u vidu da, iako Zakon o praznicima ne nameće nikome da proslavlja Dan Republike, niti propisuje obavezu u učešću u obilježavanju, ipak nameće neradni dan svima (U-3/13: 46).

Mi ovdje nećemo ulaziti u problem nadležnosti, koji su istakli mnogi komentatori, a između ostalog i NSRS u svom odgovoru, ali i sudija Ustavnog suda $\mathrm{BiH}$, Miodrag Simović u izdvojenom mišljenju po toj odluci. Naime, radi se o tome da Evropska konvencija kao i Međunarodna konvencija ne tretiraju pravo na obilježavanje praznika, pa je zahtjev neprihvatljiv ratione materiale (U-3/13:25,33). Nije, naime, jasno na šta se podnosilac poziva in concreto.

U svom odgovoru NSRS pobijala je prethodne argumente na sljedeći način. Argumenti iz klase „istorijskih“ (I) i (II) formalno su netačni jer je predmetni Zakon o praznicima usvojen 2007. godine u NSRS koja je bila multietnička i uključivala u zakonodavni proces i političke predstavnike Hrvata i Bošnjaka (U-3/13: 24; 30). „Vjerski“ argument (IV) osporen je sa stanovišta da Zakonom o praznicima Dan Republike nije označen kao vjerski praznik, niti da ima bilo kakve religijske konotacije (U-3/13: 31; 49; 50). Takođe, tvrdi se da je sam tekst Zakona o praznicima apstraktan i etnički/ religijski neutralan, te da je podudaranje s pravoslavnim svecem čista koincidencija. Imajući u vidu religijsku kompleksnost bosansko-hercegovačkog društva, bilo bi praktički nemoguće pronaći bilo koji datum koji se ne bi podudarao s nekim religijski važnim datumom neke od konfesija (U-3/13:26). Posebno je istaknuto da se Zakonom o praznicima zapravo jasno razdvajaju republički i vjerski praznici, i u oba slučaja garantuje jednakost svih (U-3/13: 37). A naročito je istaknuta činjenica da „krsna slava RS nikada nije ustanovljena niti jednim propisom u RS“, računajući i Zakono slavama i svetkovinama i Zakon o praznicima (U-3/13: 73). Argument „praksa“ (V) osporen je konstatacijom da Zakon o praznicima ne propisuje način proslavljanja te da pozivanje na „praksu“ proslavljanja, nema nikakvog zakonskog odraza: „stoga ne može biti označen(a) kao 'zakonita' ili 'nezakonita'“ (U-3/13: 31). ${ }^{9}$ Ustavni sud može se baviti isključivo zakonskim aktima - tj. pitanjem da li je neki zakon ustavan ili nije; u ovom slučaju diskriminatoran ili nije; a ne praksom koja slijedi iz tog zakona. Zadatak Ustavnog suda jeste da se bavi kvalifikacijom norme, a ne prakse (U-3/13:73). S obzirom na to da zakon nije diskriminatoran, a Ustav RS propisuje zabranu diskriminacije, onaj ko organizuje diskriminatornu praksu podliježe krivičnom zakonu i sudovima RS. Upravo zato je odredba Zakona o praznicima koja propisuje neradni dan ${ }^{10}$ tako suštinska za cijeli slučaj, jer ona uvodi „pozitivnu“ diskriminaciju, tj. prinudu. Argumenti (II) i (III) osporeni su upravo pozivanjem na logiku sadržanu $\mathrm{u}$ argumentu (VI): naime, zakonodavac je upravo želio izbjeći diskriminaciju po etničkoj/ religijskoj osnovi time što je Dan Republike proglasio kao praznik svih građana RS i svima obezbijedio jednako pravo na neradne dane, tj. plaćeno odsustvo (U-3/13: 51). Propisati da samo oni koji slave Dan Republike imaju pravo na plaćeno odsustvo upravo bi bila očita diskriminacija prema onima koji ne žele da slave i/ ili se ne identifikuju s tim

\footnotetext{
9 Proslavljanje praznika stvar je javnog prava $\mathrm{u}$ kome vlasti „uživaju široko polje slobodne procjene“ (U-3/13: 64), pa stoga osporavanje prakse obilježavanja teško može naći osnovu u komparativnom pravu.

${ }_{10}$ S druge strane stvari kao što je liturgija ili sporna pozivnica nediskriminatorne su jer ne propisuju da neko mora učestvovati u toj praksi.
} 
danom. U postojećem rješenju nije propisana obaveza da se slavi, već pravo na neradni dan.

Analizirajući ove argumente i kontrargumente Ustavni sud $\mathrm{BiH}$ stao je na stanovište da su argumenti iz klase „istorijskih“ korektni i da je „9. januar ... inspirisan 9. januarom 1992. godine, ... kao izraz političke volje samo jednog, srpskog naroda“ (U-3/13: 78), te da kao takav „nema simboliku kolektivnog sjećanja“ što je obavezno za praznik kakav je Dan Republike, koji „kao takav mora predstavljati sve građane RS“ (U-3/13: 79). U tom smislu ovaj datum ne može se smatrati „saglasnim s osnovnim vrijednostima izjavljenim u Ustavu RS“ (U-3/13: 79).

Ustavni sud $\mathrm{BiH}$ prihvatio je i „religijsku“ argumentaciju (U-3/13: 88-94), premda Ustavni sud $\mathrm{BiH}$ prihvata da Zakon o praznicima ne povezuje Dan Republike s vjerskim praznikom Svetim Stefanom, a takođe konstatuje da taj zakon ne propisuje bilo kakvu praksu obilježavanja (U-3/13: 80). Ipak, Ustavni sud $\mathrm{BiH}$, polazeći od defincije diskriminacije kao prakse u kojoj „se lice ili grupa lica koji se nalaze u analognoj situaciji različito tretiraju a da ne postoji objektivno i razumno opravdanje za takav tretman" (U-3/13: 81), prihavata da 9. januar u kontekstu prakse njegovog obilježavanja predstavlja favorizovanje pravoslavne religije i srpskog naroda (U-3/13: 96-97). Ustavni sud $\mathrm{BiH}$ je na stanovištu da je „nevažno da li je diskriminacija posljedica različitog zakonskog tretmana ili primjene samog zakona" (U-3/13: 81). ${ }^{11}$ Činjenica da je Ustavni sud $\mathrm{BiH}$ prihvatio da razmatra "praksu“ sama po sebi više je nego problematična, a u kontekstu osporavanja nekog zakona na osnovu prakse njegove primjene djeluje i potpuno apsurdna. Naime, time se ne može tvrditi da je zakon

\footnotetext{
11 Ovim se otvorilo teorijski važno pitanje „,administrativne prakse suprotne Konvenciji“(U-3/13: 84), jer način obilježavanja praznika „dobija karakter vršenja javne vlasti“ (U-3/13: 82).
}

neustavan - šta, na primjer, ako se praksa primjene naprosto promijeni ${ }^{12}$ : u ovom slučaju eliminišu religijski sadržaji iz manifestacija obilježavanja. Da li bi tada Ustavni sud $\mathrm{BiH}$ prosudio drugačije o datom zakonu? Ili, kako je to odlično primijetio sudija Knežević: „proizilazi da je od nas (Ustavnog suda) traženo da, u stvari, proglasimo neustavnom normu koje nema!“ (U-3/13: 39).

$\mathrm{U}$ obje magistralne linije argumentacija dotiče dva kontroverzna pitanja savremene jurisprudencije: na koji način se ustavnopravno mogu tretirati „pasivne“ povrede nečijih osjećanja (takve koje nastaju samim aktom nekog pojedinca/ grupe, bez prinude ostalih na učešće); i da li ustavni sudovi uopšte mogu meritorno odlučivati o „praksi“, tj. pojedinačnom aktu, ili samo i isključivo o zakonima. ${ }^{13}$ Nažalost, Ustavni sud $\mathrm{BiH}$ ovdje je ponudio vrlo šturo i gotovo nemušto opravdanje svojih postupaka. Ni na prvu ni na drugu temu nije moguće destilisati jasno stanovište koje je Ustavni sud $\mathrm{BiH}$ zauzeo, te njegova odluka zaista ostavlja utisak ad hoc. Time je dao vjetar u leđa onima koji tvrde da je u pitanju politički sud. Međutim, obje stvari se mogu vrlo snažno braniti. Na primjer, Ustavni sud može da ima ovlasti da prosuđuje praksu kada ona krši bazična ljudska prava, i ovaj slučaj je bio odličan primjer na kome se to teorijsko i filozofsko stanovište (kome je sklon i autor ovog teksta) moglo braniti. Naročito je to lako moguće u situaciji kakva

12 Ustavni sud BiH iznio je sljedeći argument: „S obzirom na to da se svaki praznik obilježava na godišnjem nivou ... praksa načina obilježavanja jednog praznika potpada pod sistem, a ne izoliran slučaj“ (U-3/13: 86). Ovo je potpuni nonsens jer se praksa, ako nije zakonski propisana, utvrđuje svake godine i moguće ju je radikalno izmijeniti.

13 „Da li je moguće kao pitanje ustavnosti ocijeniti nešto što ne postoji u zakonskoj normi, ali, ... postoji u praksi?! ... Ustavni sud ... je bio dužan da odbaci zahtjev kao nedopustiv jer Sud nema ovlaštenja da odlučuje o nečemu čega nema u normi koju preispituje“ (U-3/13:39). 
je u $\mathrm{BiH}$, čiji ustav normativno implementira relevantne antidiskriminacijske međunarodne dokumente. ${ }^{14}$ Isto tako, činjenica da je Dan Republike obavezujuće neradni dan daje prostor za „objektivizaciju“ diskriminacije, koja više nije samo „osjećaj“ već ima zakonsku refleksiju (U-3/13: 95). Ali, to je zahtijevalo da se Ustavni sud $\mathrm{BiH}$ uhvati ukoštac s obrazloženjem koje je dala NSRS objašnjavajući ideju koja stoji iza namjere zakonodavca da propiše neradni dan, naime, upravo to da izbjegne diskriminaciju onih koji ne žele da slave. Stoga, čak i ako se ne složimo s mišljenjem da je samim ulaženjem u meritorno odlučivanje u ovim stvarima Ustavni sud $\mathrm{BiH}$ „dao primat političkim naspram pravnih argumenata" (U-3/13: 35), mi moramo konstatovati da Ustavni sud $\mathrm{BiH}$ nije bio na nivou s ponuđenim obrazloženjem svojih odluka. Time je samo produbio krizu koja je nastala u atmosferi ove apelacije. Koja je još više ojačana činjenicom da je odluka donesena preglasavanjem, a da su dvojica sudija iz RS dala vrlo argumentovano izdvojeno mišljenje, po logičkoj i teorijskoj snazi nesumljivo superiorno onom iz odluke Ustavnog suda $\mathrm{BiH}$.

\subsection{U-10/16}

Politička reakcija iz RS na ovakvu odluku bila je očekivano oštra. NSRS donijela je Deklaraciju $u^{15}$, u kojoj je konstatovano da NSRS ,ističe da je osporavanje ... Zakona o

14 Ovo je krucijalna stvar u odgovoru na stanovište da se ovdje „suštinski radi o percepciji, osjećaju ... a ne prekršenoj ustavnoj normi“ (U-3/13: 38). Premda je ovo zaista, kako smo već rekli, jedan od ključnih elemenata cijele situacije, ipak nije moguće redukovati stvar na takav način jer je tvrdnja podnosioca da je prekršena ustavna norma koja postoji na osnovu eksplicitnog inkorporiranja relevantnih deklaracija. A odredba o obavezujućem neradnom danu objektivizira „osjećaj“.

15 Deklaraciju povodom zahtjeva za ocjenu ustavnosti Zakona o praznicima Republike Srpske pred praznicima pred Ustavnim sudom $\mathrm{BiH}$ u predmetu U-3/13 isključivo politički, a ne pravno zasnovan akt, čiji je prikriveni cilj negacija legaliteta i legitimiteta RS i dejtonskog ustavno-pravnog poretka $\mathrm{BiH}^{\text {“ }}$ (čl. I). Nakon toga uslijedila je Odluka o raspisivanju republičkog referenduma, u kome će biti postavljeno pitanje „Da li podržavate da se 9. januar obilježava i slavi kao Dan Republike Srpske?“"(Odluka, 2016) Time je proizvedena nova ustavna i politička kriza u zemlji, jer je uslijedio zahtjev Ustavnom sudu $\mathrm{BiH}$ za donošenjem privremene mjere kojom se privremeno obustavlja Odluka o raspisivanju referenduma. Ustavni sud je u predmetu U-10/16 usvojio zahtjev za privremenom mjerom. Politički organi RS ignorisali su ovu odluku i referendum je sproveden 25. septembra 2016. Prema zvaničnim podacima, izašlo je 680.175 ili 55,78 \% glasača od čega je 677.771 ili 99, 81\% glasao u prilog 9 . januara kao Dana Republike.

Sama odluka Ustavnog suda $\mathrm{BiH}$ o donošenju privremene mjere kojom se obustavlja primjena Odluke o referendumu kontroverzna je i proizvodi niz kako političkih tako i pravnih pitanja. Mi ćemo se ovdje osvrnuti na samo neke od kompleksnosti ovog slučaja. Prvo, sam referendum kao takav je u tekstu pitanja potpuno nesporan. Prema Ustavu RS (čl. 70), RS ima pravo da raspiše referendum o bilo kom pitanju. Referendum je prema Ustavu RS neobavezujući i odluku o referendumskom pitanju donosi NSRS. Ta odluka ne mora biti identična rezultatima glasanja građana, a ne mora uopšte ni biti donesena. Događa se samo to da NSRS „pita“ građane šta misle o nekom pitanju, da bi imala potpuniji uvid prilikom donošenja odluke. Predsjednik RS je u pravu kada kaže da je referendum „neka vrsta ankete“. Narav-

Ustavnim sudom Bosne i Hercegovine u predmetu U-3/13; br.: 02/1-021-457/15, od 17. aprila 2015. godine. 
no, kada se referendum dogodi i veliki broj građana izađe i glasa za jednu opciju, NSRS teško može ignorisati tu informaciju, jer bi se tim ignorisanjem postavilo pitanje legitimiteta NSRS - naime, koga ti ljudi predstavljaju? Ali, suština je da je referendum tek faza u proceduri donošenja odluke, on sam po sebi ne stvara nikakvu odluku, već je „konsultativan“ i samo daje informaciju nadležnom organu o većinskoj volji. Zato se njegova svrha i definiše kao „prethodno izjašnjavanje“.${ }^{16}$ Upravo ova činjenica da „odluka o referendumu nema karakter zakonodavnog akta“ (U-10/16: 8; 17) je razlog zašto se može ostaviti sloboda bez ikakve restrikcije u sadržaju pitanja. Stoga je odluka Ustavnog suda $\mathrm{BiH}$ o suspendovanju („privremenom obustavljanju“) referenduma krajnje besmislena: to je kao osporiti ustavnost nekog zakona koji je još u nacrtu/ prijedlogu. Istovremeno, odluka je i skandalozna: ona u suštini predstavlja pokušaj zabrane (doduše „privremene") građanima RS da slobodno iskažu svoj stav! U tom kontekstu posmatrano, to je antidemokratski i anticivilizacijski akt. To je jednoznačno zabrani slobode govora: mi, naime, imamo pravo govoriti i komentarisati šta god želimo, ali nemamo, naravno, pravo donositi i zakone kako nam se prohtije. $\mathrm{Na}$ primjer, mi možemo misliti i govoriti šta nam padne na pamet o plavušama, ali ne smijemo, razumije se, donijeti zakon kojim bismo zabranili plavuše u RS. Imajući u vidu prethodno rečeno, građani RS imaju neotuđivo „prirodno“ pravo da iskažu svoj stav o bilo čemu; a pokušaj Ustavnog suda da to spriječi predstavlja pravi pravcati pravni skandal.

Jedno od ključnih pitanja u ovom svemu očigledno je i pitanje nadležnosti. Naime, nije jasno na osnovu čega Ustavni sud $\mathrm{BiH}$ uopšte može uzeti u razmatranje referendum,

16 To je nedvosmisleno definisano u Zakonu o referendumu i građanskoj inicijativi (ZRGI), član 2/1. jer je pravo raspisivanja referenduma izričita nadležnost entiteta, u ovom slučaju NSRS. S obzirom da referendumsko glasanje ne proizvodi pravnu činjenicu, „nije zakonodavni akt“, koji bi eventualno mogao biti u suprotnosti s Ustavom $\mathrm{BiH}$, nije jasno gdje se nalazi osnova za uključivanje Ustavnog suda $\mathrm{BiH}$ u ovu stvar. Pitanje nadležnosti potenciramo jer se u ovim kontraverznim slučajevima jasno vidi intencija Ustavnog suda $\mathrm{BiH}$ da proširi svoje nadležnost na materiju koja mu po prirodi stvari ne potpada pod nadležnost.

Suština zahtjeva za privremenom mjerom može se svesti na dvije tvrdnje/ argumenta (U-10/16:5): (I) prvo, podnosilac tvrdi da je time osporen autoritet Ustavnog suda $\mathrm{BiH}$ (U-10/16: 6) čime je de facto osporen ustavnopravni poredak države, tj. član VI/5 Ustava $\mathrm{BiH}$; i (II) time se narušava nesmetano funkcionisanje demokratskog procesa u državi, tj. krši član I/2 Ustava BiH.

Što se tiče prvog argumenta, stvar je više nego jasna: NSRS jasno je dala do znanja da joj je referendum neophodan u procesu implementacije odluke U-3/13 (U-10-16: 16, 19). Osim toga, sama činjenica da referendum u RS nije obligatorni, već konsultativni, čini apsurdnom tvrdnju da se njegovim sprovođenjem može osporavati obavezujući karakter odluke U-3/13 (U-10-16: 17). Dakle, ni na koji način se ne negira volja da se ispoštuje odluka Ustavnog suda $\mathrm{BiH}$. To je trezvena i dobra reakcija: odbijanje da se sprovede odluka jasno i nedvosmisleno značilo bi izlazak iz ustavnog poretka i suspendovanje političkog ugovora koji je trenutno na snazi, a za koji je nemoguće da funkcioniše bez Ustavnog suda. Ustavni sud je dio ustava $\mathrm{BiH}$, a ustav je Annex 4 DPA. Shodno toj logici, neprihvatanje odluke suda je izlazak ne samo iz postojećeg ustavnopravnog poretka države već i iz „dejtonskog“ aranžmana. Upozorenje koje je došlo od strane Gianni Buquicchio 
(Buquicchio, 2017), predsjednika Venecijanske komisije, upravo u tom smislu jasno kaže da odluke Ustavnog suda moraju imati snagu konačnosti i neopozivosti, i da se moraju prihvatiti. $^{17}$

Što se tiče drugog argumenta vezanog za kršenje člana I/2 Ustava $\mathrm{BiH}$ on u apelaciji

17 Ali to ne znači da to prihvatanje mora i treba biti bespogovorno. Moderna teorija konstitucionalizma jasno objašnjava metodu kojom se može suprotstaviti odluci koja je proceduralno ispravna u svim koracima donošenja kroz politički sistem (računajući i filter Ustavnog suda), a ipak se od određene grupe ljudi (u našem slučaju velike većine jednog naroda) smatra nepravednom. Taj metod se najčešće imenuje terminom „građanska neposlušnost“. Ovaj rolsovski termin definiše situaciju konstantnog otpora i osporavanja odluke, ali bez izlaska iz političkog sistema. Mi se borimo protiv odluke, kroz institucije sistema i nekom vrstom ,institucionalne gerile“ - polemikom, osporavanjem, javnom kampanjom, konstantnom kritikom itd. sve dok (i ako) ne izdejstvujemo promjenu. Referendum je upravo jedan takav metod - mi želimo izvršiti pozitivan pritisak na Ustavni sud $\mathrm{BiH}$, tako što ćemo ga prima facie suočiti s apsurdnošću njegove odluke: koja je u suprotnosti s istorijskim faktima, stvarnošću i dominantnom voljom velike većine građana (u ovom slučaju $99,81 \%$ od $55,78 \%$ izašlih na referendum). Ništa od ovoga nije niti nužan niti dovoljan razlog da bi se neka odluga Ustavnog suda dovela u pitanje. Npr. čak i kada bi $100 \%$ građana RS glasalo na referendumu „Za“ zabranu plavuša, i svih 83 poslanika NSRS glasalo „Za“ takav zakon, on ne bi mogao biti usvojen jer krši prirodno pravo svake osobe da bude vlasnik nad svojim tijelom. Prema tome, takav zakon bio bi pobijen od strane Ustavnog suda, i to sasvim legitimno. Ipak, činjenica da ovako velik broj građana podržava osporavanje odluke Ustavnog suda, nije irelevantna i sudije moraju da ozbiljno argumentuju svoje odluke. U ovom se kontekstu mi ne možemo složiti s gospodinom Buquicchio-om: naša namjera zaista jeste da osporimo legitimitet konkretne odluke Ustavnog suda, kao i sam Ustavni sud zbog njegove, po našem mišljenju, nekorektne prakse. I mi imamo pravo na to. Ali mi ne želimo ukinuti Ustavni sud tako što ćemo proglasiti njegove odluke ništavnim - naprotiv: zvaničan stav iz RS jeste da je referendum jedan „korak u provođenju odluke Ustavnog suda“. Prema tome, mi imamo identičnu poziciju koju je zauzeo Sokrat u Apologiji, a koja je bez sumnje prihvaćena kao legitimna (i čak jedino ispravna) u pravnoj tradiciji Zapada: mi smatramo da sudije ne čitaju pravo na ispravan način i želimo im skrenuti pažnju na to. To nije želja ili zahtjev da se ukine ili ospori jedna institutcija (Ustavni sud), već da se poboljša njegov rad. takođe ima dva konteksta. Jedan je svodiv na prethodni - da nepoštovanje Ustavnog suda $\mathrm{BiH}$ ugrožava demokratsku strukturu države (U-10/16: 11). Kao takav, nije ovdje od značaja ako se uzme u obzir odgovor koji je NSRS dala na prvi argument - naime da je referendum u funkciji provođenja odluke U-3/13. Međutim, drugi argument iznosi i jednu suptilnu stvar koja zaslužuje ozbilinu pažnju, a tvrdi se sljedeće:

„Provođenje ovog referenduma u vrijeme predizborne kampanje za lokalne izbore može itekako utjecati na izborne rezultate, što će se reflektirati na legitimitet vlasti $u$ naredne četiri godine. S druge strane, ako se provođenje referenduma privremeno zaustavi, sobzirom na to da se ne radi o gorućem pitanju, posljedice privremenog zaustavljanja neće biti nepovratne" (U-10/16:14).

Ovim se tvrdi fundamentalna stvar: sprovođenje referenduma neposredno pred izbore dovodi u pitanje izborni proces i demokratski legitimitet budućih izabranih predstavnika. Inače, to je tvrdnja koju je iznio i veliki broj opozicionih stranaka u RS. Otuda pozivanje na član I/2 Ustava BiH koji referiše na antidemokratski efekat referenduma. Nažalost, odluka da se referendum sprovede neposredno pred lokalne izbore dala je snažan argument apelaciji i bazu Ustavnom sudu $\mathrm{BiH}$ da, u ime odbrane člana $\mathrm{I} / 2$, zahtijeva "privremeno odgađanje“. Naša argumentacija iz prethodne strategije pada u vodu na ovoj tački: niko vam ne sprečava da govorite, $\mathrm{i}$ da se izjasnite referendumski o bilo čemu, ali ne smijete zloupotrebljavati (U-10/16: 9) svoje pravo da narušavate normalno funkcionisanje demokratskog procesa u državi, u ovom slučaju izbora. Osim toga, Ustavni sud $\mathrm{BiH}$ prihvatio je tzv. „test dvostruke hipoteze" (U-10/16: 14), kojim se vaga proporcionalnost posljedica u oba scenarija. Očito je da bi u slučaju privremene mjere: (I) ako 
je podnosilac u pravu, tada bi narušavanje izbornog procesa bilo nepovratno; (II) a ako nije u pravu, šteta bi bila minimalna jer je referendum moguće bez ozbiljnih posljedica organizovati nakon izbora. ${ }^{18}$

\subsection{U-18/16 i U-22/16}

Kao posebna vrsta reakcije na odluku U-3/13 uslijedilo je zahtjev U-18/16 za preispitivanje Zakona o proglašenju 1. marta Danom nezavisnosti Republike Bosne i Hercegovine (Službeni list $\mathrm{RBiH}$, br. 9/95) i u-22/16 za preispitivanje Zakona o proglašenju 25. novembra Danom državnosti Republike Bosne i Hercegovine (Službeni list $\mathrm{RBiH}$, br. 9/9). U oba slučaja Ustavni sud $\mathrm{BiH}$ odbio je zahtjeve kao neutemeljene. Podnosilac, u ovom slučaju NSRS, tvrdila je da ovi zakoni krše tačno analogne ustavne i konvencionalne odredbe kao što je to bio slučaj u U-3/13: Ustav BiH, čl. I/2 i čl. II/4, te Evropsku konvenciju za zaštitu ljudskih prava i osnovnih sloboda, čl. 14 i čl. 1 Protokola br. 12; i Medunarodnu konvenciju o ukidanju svih oblika rasne diskriminacije, čl. 1.1 i čl. 2stavak 1 a), b), c), d) i e). Argumentacija je takođe bila analogna:

I Doneseni su protivno volji srpskog naroda;

II Ovi praznici predstavljaju istorijsko sjećanje samo Bošnjaka i Hrvata, pa su Srbi u diskriminatornom položaju (U-18/16:8;10);

Ustavni sud $\mathrm{BiH}$ iznio je sljedeće. Kao odgovor na prvu primjedbu Ustavni sud $\mathrm{BiH}$ konstatovao je propoziciju kontinuiteta svih zakona koji budu na snazi na teritoriji $\mathrm{BiH}$ u momentu stupanja na snagu Ustava $\mathrm{BiH}$, ukoliko se ne kose s tim ustavom (Ustav BiH,

18 Nažalost, Ustavni sud propustio je priliku da iskomunicira s javnošću ovu argumentativnu strategiju i da predstavi svu njenu težinu. Naprotiv, slika o cijelom slučaju koja se pojavila u medijima bila je slika apsurdnosti zabrane neobavezujućeg, konsultativnog referenduma.
I/1; Aneks II/2). Time se želi pobiti tvrdnja podnosioca da su ovi zakoni de facto neprihvatljivi prema de iure logici koju je Ustavni sud $\mathrm{BiH}$ primijenio $\mathrm{u}$ analognom slučaju U-3/13. Naime, Zakon o praznicima je donesen naknadno, dok Zakon o 1. martu i Zakon o 25. novembru postoje na osnovu činjenice kontinuiteta (U-18/16: 11, 35; U-22/16: 8). Ovo je besmislen pokušaj ako se ima u vidu onaj dio rečenice iz Aneksa II/2 Ustava BiH koji kaže: „u onoj mjeri u kojoj se ne kose sa ovim Ustavom“. Podnosilac, naime, upravo to tvrdi. A to tvrdi na osnovu činjenice da su ovi datumi odabrani protivno volji srpskog naroda i kao simboli konkretnog istorijskog događaja - referenduma o nezavisnosti $\mathrm{BiH}$, na kome Srbi većinski nisu učestvovali (U-18/16:22). ${ }^{19}$ Stoga, ne samo da 1. mart predstavlja diskriminaciju na osnovu toga što promoviše (a) obilježavanje jednog istorijskog događaja u kome Srbi nisu učestvovali, (b) o kome imaju negativnu percepciju, već je i sam (c) zakon donesen bez učešća predstavnika Srba (U-18/16: 8; U-22/16: 19). U pokušaju da obrazloži neprihvatljivost ovog troslojnog argumenta (ponavljamo, potpuno analognog onom iz U-3/13), Ustavni sud $\mathrm{BiH}$ kao ključni argument navodi to da su na referendum o nezavisnosti „bili pozvani svi građani $\mathrm{BiH}$, bez ikakvih razlika i pod međunarodnom kontrolom" (U-18/16: 28; 41), što je bio i uslov koji je tzv „Badinterova komisija“ postavila kao za međunarodno priznavanje nezavisnosti. Ova argumentacija je blago rečeno problematična. Kada se razgrne stvar, Ustavni sud $\mathrm{BiH}$ tvrdi: 1. mart je kredibilan jer su svi imali pravo da uče-

\footnotetext{
19 Argumenti iz klase „istorijskih“ manje su značajni za U-22/16 jer se može tvrditi da su Srbi učestvovali, jednako kao i ostali, u događajima vezanim za ZAVNOBiH, tako da je Ustavni sud $\mathrm{BiH}$ s lakoćom pobio argumente ovog tipa (U-22/16: 25-26). Uopšte, U-22/16 je mnogo manje kontroverzan od U-18/16 i prava komaparacija može se raditi na poređenju $\mathrm{U}-3 / 13$ sa $\mathrm{U}-18 / 16$.
} 
stvuju u njemu (U-18/16: 36); dok 9. januar nije jer Bošnjaci i Hrvati nisu mogli da participiraju. Sud potpuno ignoriše činjenicu da je upravo neučestvovanje jasno izražen stav. Pogotovo ako imamo u vidu plebiscit koji su organizovali Srbi u BiH. Time je više nego jasno i nedvosmisleno iskazan stav jednog od konstitutivnih naroda o datom događaju. Ustavni sud $\mathrm{BiH}$ nije ponudio niti jedno obrazloženje zašto bi argumenti (a), (b) i (c) bili prihvatljivi u U-3/13, ali ne i u U-18/16. Nešto što se, koliko god bilo pravno nategnuta interpretacija, može smatrati koliko-toliko ozbiljnim argumentom jeste vrsta logike koja se može destilovati iz reinterpretacije istorije SFRJ i BiH a koja se odnosi na činjenicu priznavanja kontinuiteta $\mathrm{BiH}$ kao međunarodnog subjekta. Naime, Ustavni sud $\mathrm{BiH}$ upustio se u široko političko i pravno (sic!) interpretiranje novije istorije $\mathrm{BiH}$ (U-18/16: 25-37) s namjerom da ustvrdi da referendum od 1. marta ne može biti shvaćen drugačije do kao jedan od preduslova međunarodnog priznanja $\mathrm{BiH}$ te stoga kao „dio pravnog kontinuiteta" $\mathrm{BiH}$, kao ustavnog načela (Ustav $\mathrm{BiH}$, čl.I/1). S obzirom na to da su Srbi prihvatili Ustav $\mathrm{BiH}$, oni su, kao ustavotvorac, dali implicitnu saglasnost na implikacije ustavnog načela kontinuiteta:

„Konstitutivnost se ne može shvatiti tako široko da ide izvan onoga što Ustav određuje. To znači da se konstitutivni narodi (posredstvom ovlaštenih zastupnika) ne mogu sa uspjehom pozivati na kršenje konstitutivnosti na temelju nečega što bi se moglo opisati kao njihovi pogledi ili želje ili neslaganja oko odredenih pitanja (političkih, pravnih, kulturnih, povijesnih, ekonomskih itd.). Konstitutivnost može biti povrijeđena isključivo ako se ugrozi neko pravo ili odredba iz ovog ustava. U konkretnom slučaju imamo činjenicu da ovaj ustav propisuje kontinuitet Republike Bosne i Hercegovine, a naprijed je jasno obrazloženo da je međunarodno priznanje Republike Bosne i Hercegovine uslijedilo nakon referenduma održanog 29. veljače i 1. ožujka 1992. godine. Sa druge strane, stoji činjenica da su svi konstitutivni narodi, uključujući naravno i Srbe, 'odredili da je ovaj Ustav kako slijedi', uključujući naravno i odredbe o kontinuitetu Republike Bosne i Hercegovine" (U-18/16:38).

Dakle, argument (I) da su ovi zakoni doneseni protivno volji srpskog naroda, premda on ima različitu percepciju i osjećanja prema tom datumu, ne stoji ako se logika situacije razvije dovoljno daleko. Naravno, očito pitanje glasi: Zašto Ustavni sud $\mathrm{BiH}$ nije prihvatio istu logiku u U-3/13. Prema mišljenju sudije Kneževića, u uvođenju ovog istorijskog narativa u odluku radi se samo o tome da „se zamagli različito odlučivanje u sličnim ili istovjetnim zahtjevima" (U-18/16: 20), tj. prikrije kršenje elementarnog pravnog načela.

Drugi argument, o diskriminatornosti, Ustavni sud $\mathrm{BiH}$ odbacio je na najosjetljivijoj tački - obligatornosti. Problem obligatornosti neradnog dana (U-18/16: 23) je, kako smo naveli u prethodnoj argumentaciji, vezanoj za U-3/13, predstavlja jednu od ključnih stavki za objektivističko definisanje diskriminacije. U slučajevima U-18/16 i U-20/16 Ustavni sud $\mathrm{BiH}$ ocjenio je da se ne radi o diskriminaciji, premda u oba zakona postoji klauzula o obaveznom neradnom danu, na osnovu toga što ovi zakoni ne propisuju sankciju u slučaju kršenja (U-22/16: 29, 30), za razliku od U-3/13, koji predviđa „relativno visoke kazne“. Dodatno, Ustavni sud $\mathrm{BiH}$ naglasio je razliku i u kontekstu prakse obilježavanja ovih praznika, navodeći da se, za razliku od U-3/13, podnosilac u slučaju U-18/16 i U-20/16 nije pozvao ni na kakvu praksu koja bi mogla biti označena kao diskirminatorna. Prema tome, u ovim 
slučajevima nema objektivističkog odraza za „osjećaj“ diskriminisanosti, niti u normi niti u praksi. Premda ova argumentacija ima nekog osnova, ona je očito i suviše slabašan temelj za tako drastičnu razliku i drastične političke i društvene posljedice koje slijede iz nejednakog tretiranja ovih sličnih ili čak analognih slučajeva.

Kada pokušamo rezimirati komparativnu analizu ovih slučajeva, možemo kreirati sljedeći tabelarni prikaz:

\begin{tabular}{|l|l|l|l|}
\hline & Argument: & U-3/13 & U-18/16; U-22/16 \\
\hline (1) & $\begin{array}{l}\text { Diskriminacija na osnovu } \\
\text { ekskluziviteta }\end{array}$ & $\begin{array}{l}\text { 'Skupština srpskog naroda BiH' } \\
\text { još 1992. god., u kojoj nije bilo } \\
\text { predstavnika Bošnjaka i Hrvata. }\end{array}$ & $\begin{array}{l}\text { Zakoni važe po načelu } \\
\text { kontinuiteta. }\end{array}$ \\
\hline (2) & $\begin{array}{l}\text { Diskriminacija na osnovu } \\
\text { sadržaja }\end{array}$ & $\begin{array}{l}\text { Cilj, proklamovan 9. 1. 1992. } \\
\text { jeste etno-teritorijalno razgrani- } \\
\text { čenje Srba i ostalih. }\end{array}$ & $\begin{array}{l}\text { Etnički neutralan cilj referendu- } \\
\text { ma od 1. marta - uspostavljanje } \\
\text { gradanske države }\end{array}$ \\
\hline (3) & Istorijski momentum & Samo Srba & $\begin{array}{l}\text { Svi su bili pozvani na } \\
\text { referendum. }\end{array}$ \\
\hline (4) & Religijska konotacija & Sveti Stefan & Nema religijske konotacije. \\
\hline (5) & Praksa & Pravoslavna ikonografija & Nema etno-oznaka. \\
\hline (6) & Obligatornost & Neradni dan uz sankciju & Neradni dan bez sankcije \\
\hline
\end{tabular}

Postaje očigledno da je neodrživa razlika u argumentima. Naročito je argument (3) jasna situacija: pobiti tvrdnju o „istorijskom momentu“ pozivanjem na to da su svi bili pozvani da učestvuju očito je neosnovano i ignoriše sasvim jasan i eksplicitan stav koji je iskazan neučestvovanjem i prethodnim plebiscitom. I argument (4) teško je zasnovati jer je podudaranje vjerskog i sekularnog koincidencija koju je u konfesinalno složenom bh društvu praktično nemoguće izbjeći. I argument (5) je po našem mišljenju neodrživa razlika jer praksa nije zakonska propozicija već promjenjiva stvar organizacije manifestacije. Argument (6) stoji, ali teško da može biti osnova koja bi bila te težine da bi odluka Ustavnog suda bila prihvaćena kao pravedna. I u argumentu (1) osporeni zakoni nisu usvojeni 1992. godine, već naknadno, i to uz učešće i političkih predstavnika Bošnjaka i Hrvata.

Upravo je obrnuto - taj bi se argument mogao primijeniti na U-18/16. ${ }^{20}$ Ovaj argument se na kraju mora prevesti na stvar „osjećanja" koja neko ima o nekom istorijskom događaju, što je apsurdno tematizovati sa stanovišta Ustavnog suda.

\section{ZAVRŠNO RAZMATRANJE}

Komparativna analiza ovih slučajeva pokazuje nekoliko stvari. Prvo, mi u ovom svemu možemo prepoznati sukob za politič-

20 Pokušaj Ustavnog suda $\mathrm{BiH}$ da izvrda ovu stvar pozivanjem na kontinuitet je, čak i ako se prihvati, striktno materijalnopravna argumentacija koja, kao takva, ne može biti podloga za jaki status nekog ustavnog suda - već ga svodi samo na čitača ima li ili nema nečega u ustavu,što onda ukida Ustavnom sudu pravo na neke ranije donesene odluke, kakva je ona o ustavnosti Suda i Tužilaštva BiH. 
ku moć dvije institucije, odnosno dva sektora vlasti. S jedne strane ima osnova za tvrdnju da Ustavni sud pokazuje pretenziju da proširi svoje ovlasti preko granica uobičajenih za ustavne sudove. On time daje za pravo onima koji tvrde da politički karakter diskrecionog organa nužnim načinom proizilazi iz njegovog položaja unutar političkog sistema. Kao takav, on logično ulazi u neku vrstu konflikta s drugim dijelovima vlasti. Tako se u slučaju razmatranom u ovom tekstu očito radi o sukobu između izvršne i zakonodavne vlasti Republike Srpske, s jedne strane, i Ustavnog suda, s druge. Razlog dodatno može biti tražen u činjenici da je sudska vlast $\mathrm{BiH}$ dio strukture vlasti koji je u stanju da ostane neovisan od volje vladajućeg političkog establišmenta u RS. Ovaj sukob nije ograničen samo na Ustavni sud već i na druge dijelove pravosudnog sistema na nivou države BiH. Na primjer, haos koji se podigao oko Suda i tužilaštva $\mathrm{BiH}$, premda utemeljen u objektivnim i opravdanim primjedbama od strane predstavnika RS, po svemu sudeći bio je motivisan i ovim razlozima (Savanović, 2016). Nedavni pritisak na sudije ovog suda preko Republičkog centra za istraživanje rata $i$ ratnih zločina i traženje nestalih lica Republike Srpske, takođe se može smatrati bitkom u ovom ratu. ${ }^{21}$ Dakle, mi odluke razmatrane u ovom tekstu možemo posmatrati kao dio jedne šire platforme u kojoj se događa konflikt između dva sektora vlasti - izvršne i zakonodavne vlasti RS i sudske vlasti BiH. Ishod je neizvjestan. Ustavni sud je dobio očekivano jaku podršku međuna-

${ }^{21}$ Centar je dostavio VSTV informaciju o devet sudija i šest tužilaca Suda i Tužilaštva BiH, u kojoj se tvrdi da su pojedine sudije tokom rata učestvovale u nezakonitom procesuiranju. VSTV je usvojio "Zaključke“ kojima se nalaže da se ove informacije utvrde. Pojedine sudije sa raznih nivoa sudskog sistema reagovale su na ovu odluku VSTVkao na direktan politički pritisak koji vlast RS vrši na nezavisnost sudstva. rodne zajednice, i, bar prema dostupnim informacijama, nepoštovanje odluke Ustavnog suda bio je jedan od glavnih argumenata za sankcije koje je npr. administracija SAD uvela prema predsjedniku RS.

Ali, mora se konstatovati da postoji osnova u tvrdnjama političkih predstavnika RS da tu nije u pitanju sukob između dvije grane vlasti - izvršne vlasti RS i Ustavnog suda $\mathrm{BiH}$, već zapravo sukob između vlasti RS i vlasti bošnjačkog političkog establišmenta koji instrumentalizuje Ustavni sud $\mathrm{BiH} .{ }^{22}$ Činjenice da su odluke u slučajevima U-3/13 i U 18/16 donesene s izdvojenim mišljenjima sudija koje je u Ustavni sud $\mathrm{BiH}$ imenovala NSRS, pojačava ovu sumnju, i zapravo joj daje vrlo snažan argument, naročito ako imamo u vidu utemeljenost tih izdvojenih mišljenja. Nažalost, Ustavni sud BiH, svojim odlukama, često nedovoljno sofisticiranim, nedovoljno obrazloženim i nedovoljno predstavljenim javnosti, ponekada i bahatim, sam dolijeva ulje na vatru sličnih sumnji. Odluke U-3/13, U-18/16 i U-22/16 upravo su tako značajne zato što, možda po prvi put u praksi odluka Ustavnog suda BiH, daju snažan, i po našem mišljenju validan argument o političkoj zloupotrebi i instrumentalizaciji Ustavnog suda. U mnogim odlukama koje je Ustavni sud $\mathrm{BiH}$

\footnotetext{
22 Ta instrumentalizacija zapravo ozbiljno ugrožava kredibilitet Ustavnog suda $\mathrm{BiH}$ i ne odnosi se samo na meritorne stvari, već zadire čak i u pitanja procedure! Tako je u svom izdvojenom mišljenju u U-18/16 sudija Zlatko M. Knežević istakao da su u slučaju U-3/13 procedure poštovane - od javne rasprave, uključivanja stručnih i međunarodnih mišljenja - oficijelno je zatraženo mišljenje Vencijanske komisije i sl., dok je u U-18/16 takav širok angažman izostao, i analogni zahtjevi su odbijeni. To svjedoči o "nepristojnoj brzini" kojom je "kompaktna većina" u Ustavnom sudu $\mathrm{BiH}$ donijela odluke, a koja ne postavlja više pitanje iz merituma, već problematizuje samu pravičnost procedure kao početno pravno načelo. Time se na očit način diskredituje položaj Ustavnog suda $\mathrm{BiH}$ i "mi klizimo ka društvenom odbijanju da se provedu naše odluke“ (U-18/16:18-19). Na taj način sam Ustavni sud BiH proizvodi krizu "pravne sigurnosti“ u državi (U-18/16:21).
} 
donio, a koje su u javnosti RS predstavljene i doživljene kao anti-RS, zapravo se može stati na stranu Ustavnog suda. Po našem mišljenju najvažniji primjer je upravo sukob oko referenduma o Sudu i tužilaštvu BiH (Savanović, 2016). Ali, takođe i odluka U-10/16, koju smo ovdje razmatrali, a za koju smo vidjeli da se u drugom dijelu argumentacije (nesmetano funkcionisanje demokratskog procesa) može prihvatiti.

$\mathrm{U}$ savremenim političkim sistemima logički je nužno postojanje neke institucije koja će biti finalni arbitrator, tj. imati diskreciono ovlaštenje za donošenje konačne odluke u sporovima, i to su po pravilu ustavni i/ ili vrhovni sudovi. Ali, diskreciona moć ne znači svemoć - ona nije neograničena i sudovi moraju argumentovati svoje odluke, tj. biti u stanju da ih odbrane pred sudom građana. Ukoliko to oni ne rade ili nisu u stanju da urade, njima će nedostajati politički autoritet da svoje odluke nametnu drugim dijelovima vlasti. Razmatrani slučajevi predstavljaju paradne premijere za ovu klasičnu temu savremene jurisprudencije. Naročito je argumentacija u važnom slučaju U-18/16 i U-22/16 ispod svakog nivoa, i predstavlja blago rečeno jedan bahat i neozbiljan tekst. Ustavni sud $\mathrm{BiH}$ nije bio u stanju da iskomunicira svoje odluke na način koji bi bio dovoljno uvjerljiv da dobije dovoljnu političku podršku za njihovu realizaciju u praksi. Naprotiv, on je zauzeo jednu introvertnu poziciju, prepuštajući svoje odluke kvazipravnim i šarlatanskim interpretacijama za dnevnopolitičke svrhe. Time zapravo Ustavni sud $\mathrm{BiH}$ sam sebe urušava, jer ne daje osnova da se podrži njegov izrazito jaki status i intencija za proširenjem nadležnosti. Umjesto toga, on ide u suprotnom pravcu: u krizu masovnog nesprovođenja njegovih odluka.

\section{REFERENCE}

Bellamy, R. (2007). Political constitutionalism: a republican defence of the constitutionality of democracy. Cambridge: Cambridge University Press.

Buquiccio, G. (2017). Statement. Posjećeno: 10.08.2017. URL: http://www.venice.coe.int/ webforms/events/default.aspx?id=2303

Dodik, M. (2017). Glas Srpske, Banjaluka, 07. 07. 2017.

Dworkin, R. (1977). Taking Rights Seriously. Cambridge, Massachusets: Harvard University Press.

Hart, H.L.A. (1994). The Concept of Law. Oxford: Clarendon Press.

Izetbegović, B. (2017). Odluka Ustavnog suda očekivana. URL: http://ba.nlinfo.com. pristupljeno: 07. 07. 2017.

Meyer, S.E. (2012). The Dayton Accords: Anchor to the Past or Bridge to the Future. Politeia,4: 51-66.

Narodna skupština Republike Srpske, Deklaracija povodom zahtjeva za ocjenu ustavnosti Zakona o praznicima Republike Srpske pred Ustavnim sudom Bosne i Hercegovine u predmetu U-3/13; br.: 02/1-021-457/15.

Narodna skupština Republike Srpske, Odluka o raspisivanju republičkog referenduma br.: 02/1-021-894/16 (Službeni glasnik RS, br.68/16).

Pravila Ustavnoga suda Bosne i Hercegovine (Službeni glasnik BiH, 22/14). 
Rawls, J. (1999). Theory of Justice. Harvard University Press.

Savanović, A. (2016). Argumentacija referenduma. The Conference Proceedings: Dejtonski sporazum - dve decenije mira i pouke:102-118

Steiner, C., Ademovic, N. (2010). Ustav Bosne i Hercegovine - komentar. Sarajevo: Konrad Adenauer Stiftung.

Ustav Bosne i Hercegovine.

Ustavni sud Bosne i Hercegovine, Odluka U-3/13 (Službeni glasnik BiH 100/15).

Ustavni sud Bosne i Hercegovine, Odluka o privremenoj mjeri U-10/16 (Službeni glasnik BiH 74/16);

Ustavni sud Bosne i Hercegovine, Odluka $U-18 / 16$.

Ustavni sud Bosne i Hercegovine, Odluka $U-22 / 16$.

Weale, A. (2013). Democratic Justice \& the Social Contract. Oxford: Oxford University Press.

Visoko sudsko tužilačko vijeće, „Zaključci VSTV-a povodom 'Informacije centra za istraživanje ratnih zločina i traženje nestalih lica Republike Srpske’.“ (26. 10. 2017).

Zakon o praznicima Republike Srpske (Službeni glasnik Republike Srpske 43/07).

Zakon o slobodi vjere i pravnom položaju crkava i vjerskih zajednica u BiH (Službeni glasnik BiH 5/04).
Zakon o proglašenju 1. marta Danom nezavisnosti Republike Bosne i Hercegovine (Službeni list RBiH, br. 9/95).

Zakon o proglašenju 25. novembra Danom državnosti Republike Bosne i Hercegovine [Službeni list RBiH, br. 9/95].

Zakon o referendumu i građanskoj inicijativi (Službeni glasnik Republike Srpske 46/10). 


\section{DISCRETION POWER}

The Constitutional court of Bosnia and Herzegovina as a "political court"?

Key words

Discretionary authority, Constitutional Court of $\mathrm{B} \mho H$, politics, judiciary, Bosnia and Herzegovina

\section{Author}

Aleksandar Savanović holds $\mathrm{PhD}$ in Political Science and he is an Associate Professor at the Faculty of Political Sciences of the University of Banja Luka

\section{Correspondence}

aleksandar.savanovic@fpn.unibl.org

Field

Political theory

\section{Summary}

This paper analyzes the political crisis produced in $\mathrm{BiH}$ society by decisions of the Constitutional Court of Bosnia and Herzegovina for cases $U-3 / 13, U-18 / 16$ and $U-22 / 16$. These cases are important case studies for the classical problem of political philosophy and contemporary jurisprudence - namely: a discretion power problem of the highest judicial institution (Supreme or/and Constitutional courts). Must the highest judicial institution be "political" by definition? Or is the "political" influence of Supreme/Constitutional courts a result of their own intention to expand their power and influence? The role, practice and legacy of the highest judicial institution in an extremely divided society, such as $\mathrm{BiH}$, is a kind of real-time experiment for this problem.

341.218:323.17

Paper received on

11.11.2017.

Paper accepted for publishing on 